\title{
マルチスケール有限要素法による 板圧延プロセスメタラジー解析
}
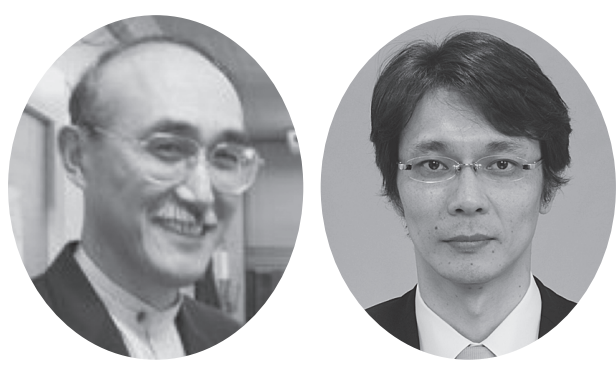

仲町 英治* . 倉前 宏行**

Journal of The Japan Institute of Light Metals, Vol. 62, No. 1 (2012) , 25-31

\section{Sheet rolling process-metallurgy analyses based on multiscale finite element method}

\author{
Eiji NAKAMACHI* and Hiroyuki KURAMAE**
}

Keywords: process-metallurgy, multi-scale, finite element, texture-design, rolling-process

\section{1. 緒言}

近年, 自動車などの板殼構造体に利用される板材料の軽量 化，高強度化および高成形能化が進んでいるが，原子や結晶 などのミクロ構造を制御することでさらなる高機能化が可能 となる事例が報告されるようになってきた。材料特性と材料 加工プロセスをミクロの視点から解析することが可能な結晶 塑性マルチスケール有限要素解析手法の開発が進んだためで ある。この解析手法と離散最適化手法を組合せることで新規 材料の創製が可能なプロセスメタラジー解析手法1) 3) が確 立される。本解説では著者らの板圧延加工プロセスに関する 事例により本解析手法について説明する。

金属板材料は圧延加工や熱処理などにより結晶方位分布に プロセスに依存した方位の偏りを生じる。これを集合組織と 呼び, この偏りにより生じる塑性異方性を巧妙に利用するこ とで, 割れ, しわ, 残留応力, スプリングバックなどの不良 発生を防止することが可能となり, 結果として高成形能板材 料が創製できる。現在，結晶集合組織の制御手法としては結 晶粒微細化も同時実現可能な強せん断加工, 異周速圧延, 繰 返し反転多層化圧延などいくつか提案されているが，本解説 では最も実現性の高い異周速圧延 ${ }^{4)}$ を取上げ，著者らが提 案するプロセスメタラジー解析の適用事例を紹介する。さ て, 異周速圧延プロセスを支配する条件・因子には圧下率, 異周速比, 温度, 多段パス工程など多数あり, これらの条件 を求めるための実験による試行錯誤には莫大な時間と費用が 必要である。そこで本解説では, 実験に先立って, 板材料が 理想的な集合組織を持つための最適圧延条件および圧延前板 材料のテイラード結晶集合組織（ここでは理想の結晶集合組 織を持つ材料を仕立てることを意味する）を予測するプロセ スメタラジー解析について説明する5) 7)。

\section{2. 結晶均質化有限要素法の概要 ${ }^{6), 8,9)}$}

図 1 に示すように体積 $\Omega$ の視連続体において任意の物体
点で周期性を満足する微視結晶体代表体積要素（RVE: Representative Volume Element）を考える。巨視連続体および 微視結晶体RVEで定義される座標 $x_{i}$ および $y_{i}$ はスケール比 $\lambda$ を用いて関係づけられる。

$$
y_{i}=x_{i} / \lambda
$$

解析対象 $の$ 体積 $\Omega$, 表面積 $\Gamma_{\sigma}$, 質量密度 $\rho$, 粘性係数 $\nu$, 外力 $\bar{T}_{i}$ (外力が作用する境界面を $\Gamma_{\sigma}$ とする), 物体力 $\bar{f}_{i}$, および巨 視連続体の変位を $U_{i}$ として, 巨視連続体の仮想仕事率の原 理式をつぎに示す。

$$
\begin{aligned}
\int_{\Omega} \rho \ddot{U}_{i}(x) \delta \dot{U}_{i}(x) d \Omega+\int_{\Omega} v \dot{U}_{i}(x) \delta \dot{U}_{i}(x) d \Omega \\
=\int_{\Omega} \bar{f}_{i} \delta \dot{U}_{i}(x) d \Omega+\int_{\Gamma_{\sigma}} \bar{T}_{i} \delta \dot{U}_{i}(x) d \Gamma \\
\quad-\int_{\Omega} \sigma_{i j}^{H}(x) \frac{\partial \delta \dot{U}_{i}(x)}{\partial x_{j}} d \Omega
\end{aligned}
$$

式（2）を解くことで得られた速度勾配を用いて微視寸法に スケールダウンすることで微視結晶体の仮想仕事率の原理式 を求めることができる。

$$
\begin{gathered}
\int_{Y} \rho \ddot{u}_{i}(x, y) \delta \dot{u}_{i}(x, y) d Y+\int_{Y} v \dot{u}_{i}(x, y) \delta \dot{u}_{i}(x, y) d Y \\
\quad=-\int_{Y} \sigma_{i j} \delta \dot{u}_{i, j}(x, y) d Y
\end{gathered}
$$

ここで， $u_{i}$ および $Y$ は微視結晶体における変位および体積で ある。仮想仕事率の原理式に有限要素離散化を導入すること で微視および巨視スケールの有限要素式を求めることができ る。微視結晶体に関する有限要素式を解くことでCauchy応 力 $\sigma_{i j}$ が算出できる。微視結晶有限要素全体の応力の平均值を

*同志社大学生命医科学部医工学科（产 610-0394 京都府京田辺市多々羅都谷 1-3）。Dept. of Biomedical Engineering, Doshisha University (1-3 Miyakodani, Tatara, Kyotanabe, Kyoto 610-0394).E-mail: enakamac@mail.doshisha.ac.jp

**大阪工業大学工学部技術マネジメント学科 (大阪市)。Department of Technology Management, Osaka Institute of Technology (Osaka-shi, Osaka). 受付日：平成23年3月14日＼cjkstart受理日：平成23年 8 月 12 日 

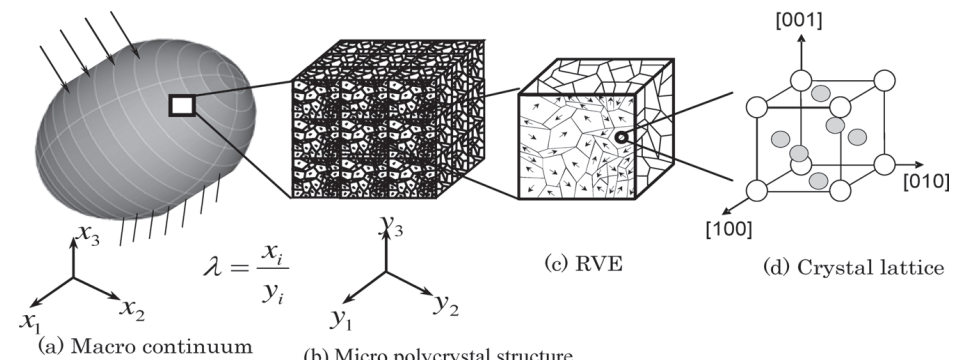

図1 2スケール構造体 巨視連続体と微視結晶構造体

\begin{tabular}{|c|}
\hline EBSD \\
\hline 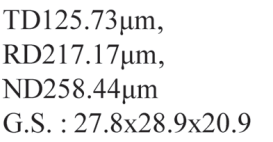 \\
\hline RVE \\
\hline 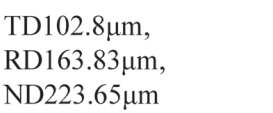 \\
\hline $\begin{array}{l}\text { Micro FE model } \\
(216 \text { orientations) }\end{array}$ \\
\hline
\end{tabular}

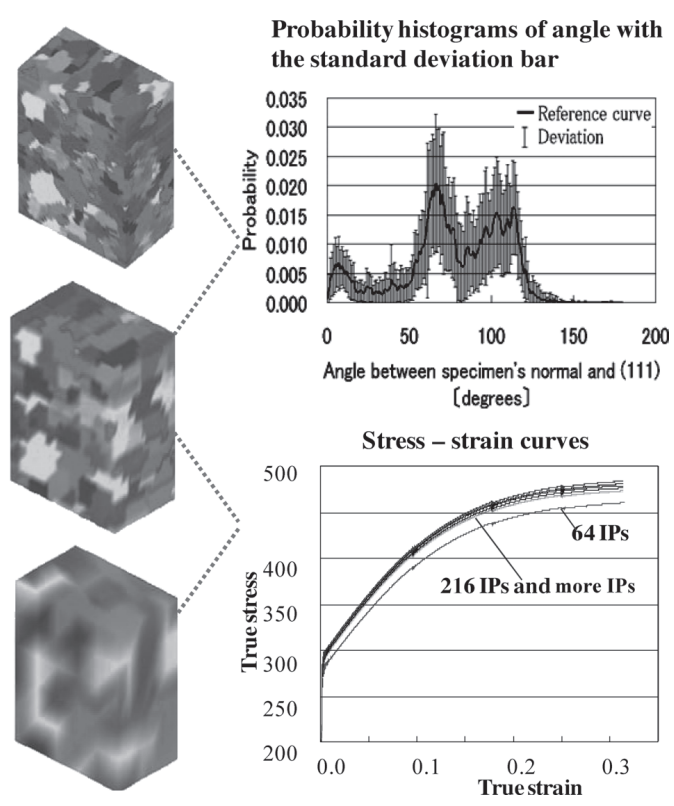

図2 三次元モデル：EBSD計測母集団モデル, EBSD計測RVEおよび微視有限要素 RVE

均質化值と考え巨視連続体の有限要素の積分点に割当て, 巨 視有限要素式を解くことになる。以上の解析プロセスによ り, 多結晶体の不均質な変形および応力を求めることがで き，集合組織発展を記述することができる。

微視結晶体に対する弾/結晶粘塑性構成式として, つぎに 示すPan-Rice ${ }^{10)}$ らの提案によるせん断ひずみ速度依存型構 成式を用いる。

$$
\dot{\gamma}^{(a)}=\dot{\gamma}_{0}^{(a)}\left[\frac{\tau^{(a)}}{g^{(a)}}\right]\left[\left|\frac{\tau^{(a)}}{g^{(a)}}\right|\right]^{(1 / m)-1}
$$

ここで $\dot{\gamma}_{0}^{(a)}$ は基準せん断ひずみ速度， $a$ はすべり系， $m$ はひず み速度感受性指数である。基準分解せん断応力 $g^{(a)}$ の硬化発 展式を以下に示す。

$$
\begin{gathered}
\dot{g}^{(a)}=\sum_{b=1}^{12} h_{a b}\left|\dot{\gamma}^{(b)}\right| \\
h_{a b}=q_{a b} \frac{d \tau(y)}{d \gamma}+\left(1-q_{a b}\right) \frac{d \tau(y)}{d \gamma} \delta_{a b} \\
\tau(\gamma)=\tau_{0}+h_{0}\left\{C\left(\gamma_{0}+\gamma\right)\right\}^{n} \\
\frac{d \tau(\gamma)}{d \gamma}=h(\gamma)=h_{0} n C\left\{C\left(\gamma_{0}+\gamma\right)\right\}^{n-1}
\end{gathered}
$$

ここで， $h_{a b}$ はすべり系（b）が活動した際のすべり系 $(a)$ の硬化度合いを表す硬化係数, $q_{a b}$ は潜在硬化を示す係数, $h_{0}$ は初期硬化係数, $n$ は硬化指数, $C$ は硬化係数, $\tau_{0}$ は臨界分
解せん断応力である。 $\delta_{a b}$ はクロネッカーのデルタであり, すべり系 $a$ と $b$ が等しい場合は 1 であり, 他は 0 となる量であ る。

図2に微視結晶体の有限要素モデルを導出する過程で得ら れた 3 次元モデルを示す。EBSD計測により得られた一片 $3.8 \mu \mathrm{m}$ の立方体による微視結晶体と結晶方位分布を指標とし て得られた周期性を満足する最小寸法である計測に基づく代 表体積要素 (RVE), さらに有限要素解析により確認した最 少有限要素数分割数による微視有限要素RVEを示す。

\section{3. 板圧延プロセスの最適設計}

\section{1 集合組織と成形性評価値}

図3に圧延過程での支配的な変形様式である単純せん断変 形と平面ひずみ圧縮変形による集合組織発展とランクフォー ド $r$ 值を, 典型的な圧延前の結晶方位分布ごとに比較して示 す。これにより $\{111\}$ 方位を優先方位とする材料が変形後良 好な $r$ 值を示すことがわかる。

図4に示すように, 等周速圧延によりアルミニウムは圧延 集合組織成分であるS 方位, Copper方位を有し, その後の溶 体化処理により生じた再結晶集合組織成分であるCube方位

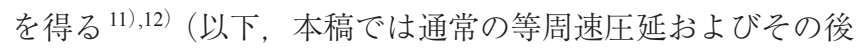
の熱処理によって得られる集合組織を $\beta$-fiber+Cube 方位と 呼ぶ)。一方で低炭素鋼であるDQSKは, 図4に示すように $\gamma$-fiber $(\langle 111\rangle / / \mathrm{ND})$ と呼ばれる $\{111\}$ 集合組織を持つ。 $\{111\}$ 
集合組織を持つ板材料は $r$ 值が高く, かつ $r$ 值の面内異方性 が小さくなる。 $r$ 值の圧延方向からの角度による変化を図 4 に示す。A16022 はDQSKに比べ $r$ 值が低く深絞り性が劣るこ とがわかる。それに対し，A16022がDQSK と同じ結晶方位 分布を持った場合の $r$ 值を結晶塑性マルチスケール解析によ り求めた $r$ 值の分布を図 4 に示す。これにより〈111〉//ND fiber（\{111\} 集合組織）を有するアルミニウム板材料は大幅 な絞り性の向上が期待できることがわかる ${ }^{13)}$ 。

\section{2 応答曲面法 (離散最適化手法 $)^{14}$}

高次の非線形性を有する有限要素解析を用いた異周速圧延 プロセスの最適設計問題であるため, 設計変数による目的関 数の陽形定式化はほとんど不可能である。そこで，可能解を 離散集合として扱う離散最適化手法に属する応答曲面法を採 用して最適条件探索を行う。評価関数（目的関数）として高 ランクフォード $r$ 值を得ることが可能な $\{111\}$ 集合組織を 採用し, 圧延プロセス因子を設計変数とし最適条件探索を行

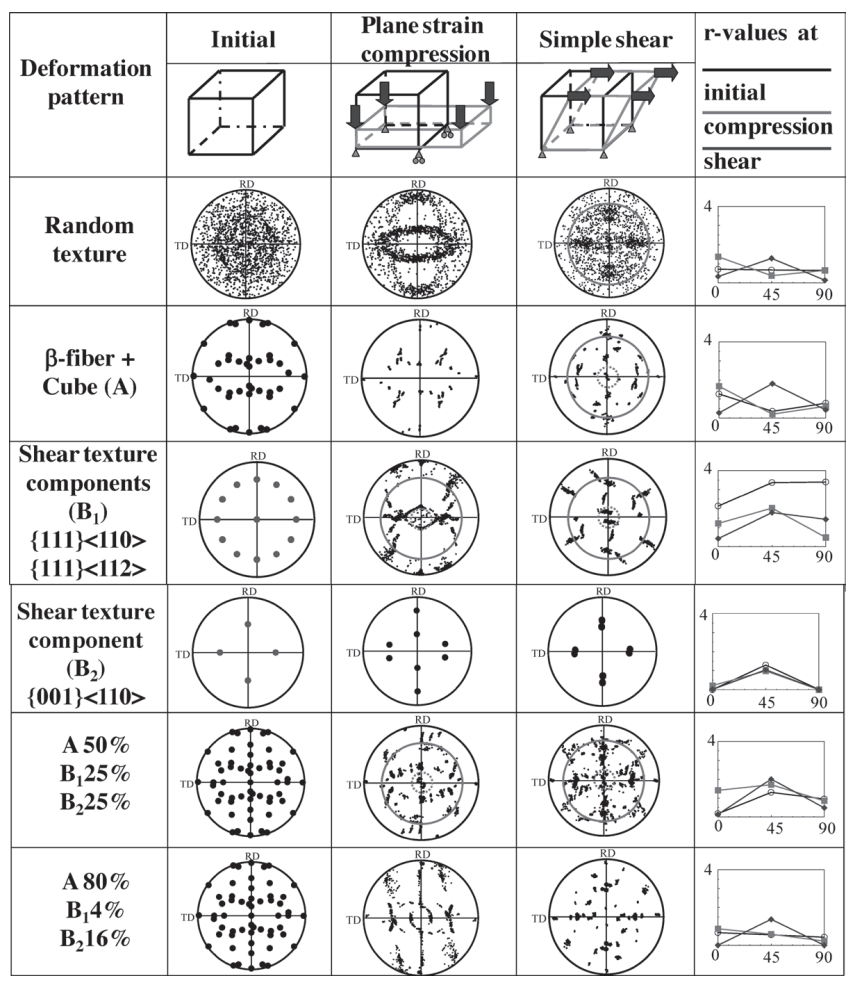

図3 せん断と圧縮変形誘起の集合組織発展と $r$ 值分 布（初期板材の結晶方位分布による相違）
う。

\section{3 結晶塑性マルチスケール有限要素解析}

圧延前の板材料（初期板材料と呼ぶ）は，6022アルミニ ウム合金に熱処理および熱間等周速圧延を行い，厚さ $6 \mathrm{~mm}$ の板材料にしたものである。初期板材料表層部には典型的な 圧延集合組織成分のS方位およびBrass方位が確認された。 さらに，溶体化処理を行っていることから，再結晶集合組織 成分であるCube方位も確認された。

つぎに，弾/結晶粘塑性構成式のパラメータの算出を行う ため, 初期板材料の単軸引張試験を行い, 図5に示す応力一 ひずみ関係を求めた。応力は温度，ひずみ，ひずみ速度に依 存するものとし，Norton則を用いて近似式を導出した。ここ では温間圧延の条件として，温度 $250^{\circ} \mathrm{C}$, ひずみ速度 $10 \mathrm{~s}^{-1}$ を採用し，この条件における応力ーひずみ関係式を求めた。

$$
\sigma=149.7 \varepsilon^{0.13}
$$

式（6）に示す応力ーひずみ関係と, 弾/結晶粘塑性有限要 素法を用いて単軸引張解析を行うことで得られる応力ーひず み関係により弾/結晶粘塑性構成式の材料特性値 $\tau_{0}=16.5 \mathrm{MPa}$, $h_{0}=22.5 \mathrm{MPa}, n=0.26, C=5.6, \gamma_{0}=0.005$ を求めた。Coulomb 摩 擦係数はロールの入口から出口にかけて図6(a) に示される ように設定した。板材料の有限要素モデルは図6(b) に示さ れるように, $0.4 \mathrm{~mm} \times 40.0 \mathrm{~mm} \times 6.0 \mathrm{~mm}$ のイズで $1 \times 160 \times 5$ 分割 $\left(800\right.$ 要素) とし,$x_{2}$ (TD) 幅方向の変位拘束を導入す ることで平面ひずみ条件を実現した。

つぎに，板圧延プロセス最適設計を行った。本最適条件探 索事例では, 目的関数を $\{111\}\langle 110\rangle,\{111\}\langle 112\rangle$ 方位への 結晶方位の集積密度とした。結晶方位分布関数ODFの存在 確率はつぎのように表される。

$$
f\left(\varphi_{1}, \Phi, \varphi_{2}\right)=\sum_{l=0}^{\infty} \sum_{m=-l}^{l} \sum_{n=-l}^{l} C_{l}^{m n} T_{l}^{m n}\left(\varphi_{1}, \Phi, \varphi_{2}\right)
$$

ここで, $f\left(\varphi_{1}, \Phi, \varphi_{2}\right)$ は結晶方位分布関数, $T_{l}^{m n}\left(\varphi_{1}, \Phi, \varphi_{2}\right)$ は 球面調和関数, $\varphi_{1}, \Phi, \varphi_{2}$ は Bunge ${ }^{15)}$ によって定義された Euler角であり, $\{111\}\langle 110\rangle$ で $\varphi_{1}=60.0^{\circ}, \Phi=54.7^{\circ}, \varphi_{2}=45.0^{\circ}$, $\{111\}\langle 112\rangle$ では $\varphi_{1}=0^{\circ}, \Phi=54.7^{\circ}, \varphi_{2}=45.0^{\circ}$ となる。設計変数 は板圧延条件である異周速比 $v$, 圧下率 $\eta$ を用い, 数理的最適 問題は以下のように設定した。

Maximize $f(v, \eta)$

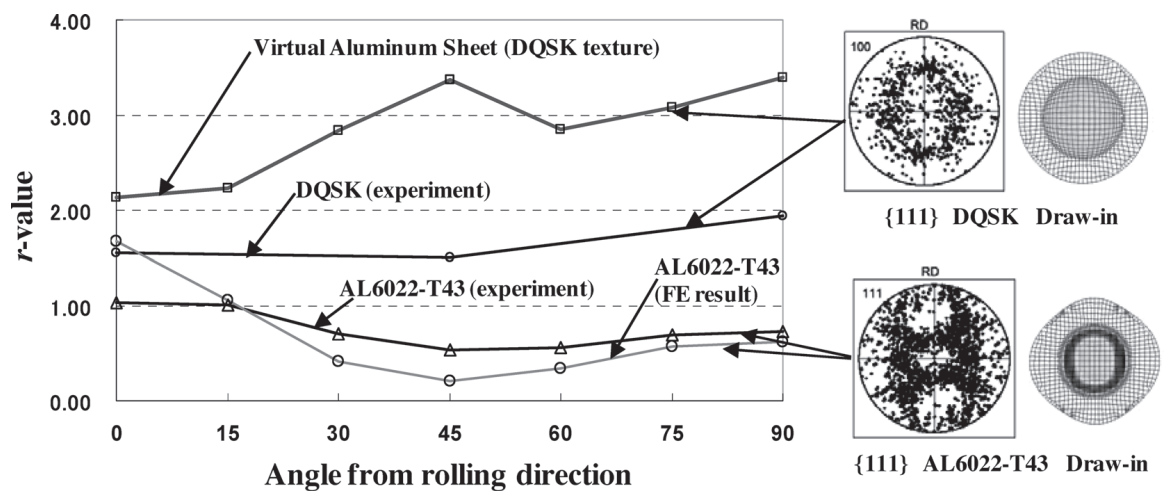

図4 ランクフォード值 $r$ と圧延方向からの角度との関係：鋼板DQSK，アルミニウム板6022-T43（実験地㧍よび結晶 塑性有限要素解析結果)，および仮想集合組織アルミニウム板材 
Subject to $1.25<v<2.5, \quad 16.7<\eta<66.7$

(9)

まず，圧下率 $\eta=50 \%$ で等周速圧延 $v=1$ および異周速圧延 $v=2$ の場合の有限要素解析結果を図7に比較して示す。変形 形状およびせん断ひずみ分布 $\left(\left|\varepsilon_{31}\right|\right)$ 分布を図 7(a-1), (b-1) に示す。等周速圧延においては表面層において強いせん断変 形が生じ，中間層に近付くに従って平面ひずみ圧縮変形が支

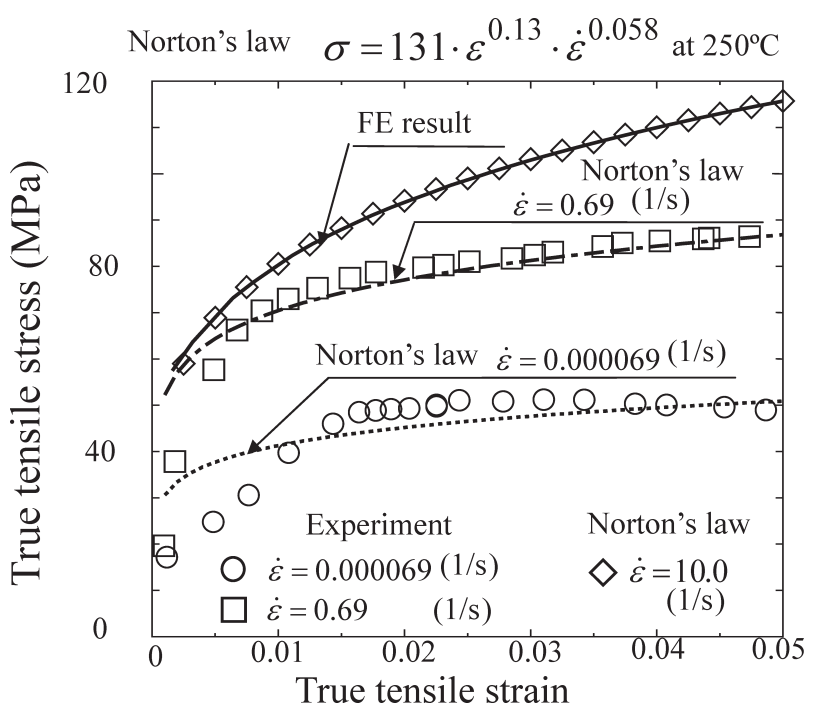

図 5 アルミニウム板材 $\left(6022\right.$, 板厚 $\left.6 \mathrm{~mm}, 250^{\circ} \mathrm{C}\right)$ の応 力ーひずみ関係：Norton則近似式と有限要素解析 による同定
配的になっている。一方で, 異周速圧延においては板厚方向 全体において強いせん断変形が生じていることが確認でき る。つぎに図中において丸で囲んだ板厚方向 5 層における \{111\} 正極点図を図7(a-2)，(b-2）に示す。初期板材料では $\mathrm{S}$ 方位 $(\{123\}\langle 634\rangle)$, Copper方位 $(\{112\}\langle 111\rangle)$ を含む典 型的な圧延集合組織が見られる。等周速圧延においては表面 層において $\{111\}\langle 110\rangle,\{001\}\langle 110\rangle$ そして $\{112\}\langle 110\rangle$ で 構成されるせん断集合組織が確認され, 中間層では平面ひず み圧縮の集合組織が確認された。異周速圧延により板厚方向 全体において典型的なせん断集合組織が確認された。そこ で, 設計変数である異周速比, 圧下率を $v=1.25,1.5,2.0,2.5$, $\eta=16.7 \%, 33.3 \%, 50.0 \%, 66.7 \%$ とした 16 条件により応答曲面 近似による最適圧延条件の探索を行った。図8に16条件の 集合組織発展の相違を $\{111\}$ 正極点図により比較して示す。 図9に，応答曲面法によって得られた 5 次の応答曲面と等高 線図を示す。これにより最適圧延条件は異周速比 $v=2.2$, 圧 下率 $\eta=58 \%$ となった。

図10に実験およびマルチスケール解析結果を比較して示 す。異周速圧延 $3 \mathrm{~mm}$ 板材料の中層部から実験，解析ともに, 正極点図においてせん断集合組織である $\{111\}$ 集合組織が 確認され，逆極点図より ND方向において [001］および [111］方向への優先方位が確認され， RD方向においては [101］方向への優先方位が確認された。実験および解析とも によい一致を示しており，これにより応答曲面近似による圧 延プロセス最適化の有効性が示された。

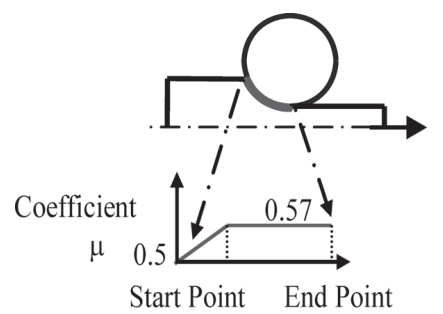

(a) 摩擦係数

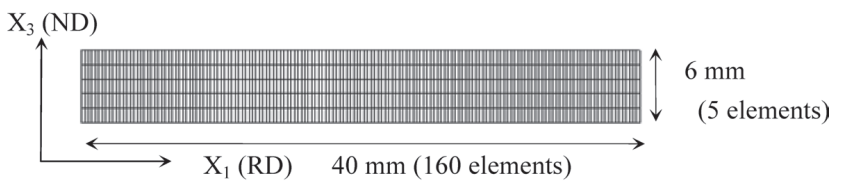

(b) 板厚 $6 \mathrm{~mm}$ の初期板材の有限要素分割図

図6 摩擦係数 (Coulomb's Law) と初期板材の有限要素分割図
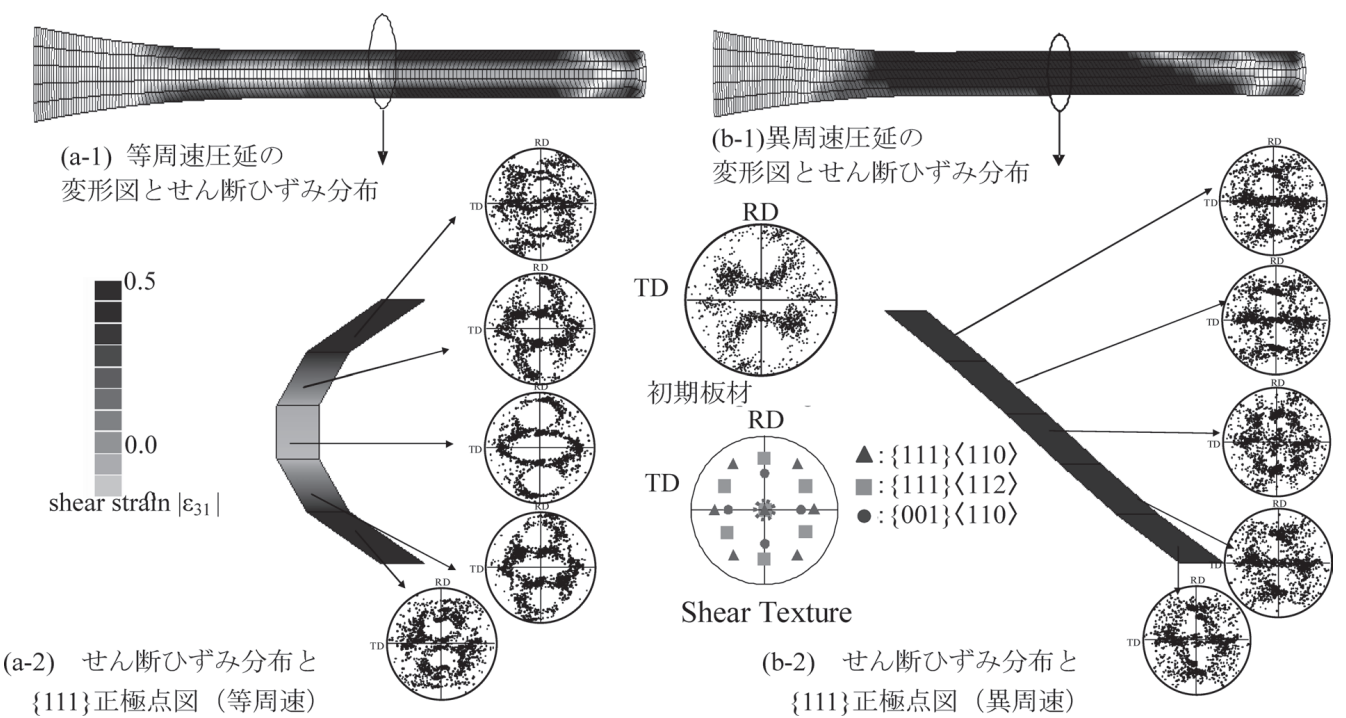

図7 等周速および異周速圧延における板短冊部切出し有限要素（板厚方向 5 層）のせん断ひずみ $\left|\varepsilon_{31}\right|$ 分布と変形図, および $\{111\}$ 正極点図 


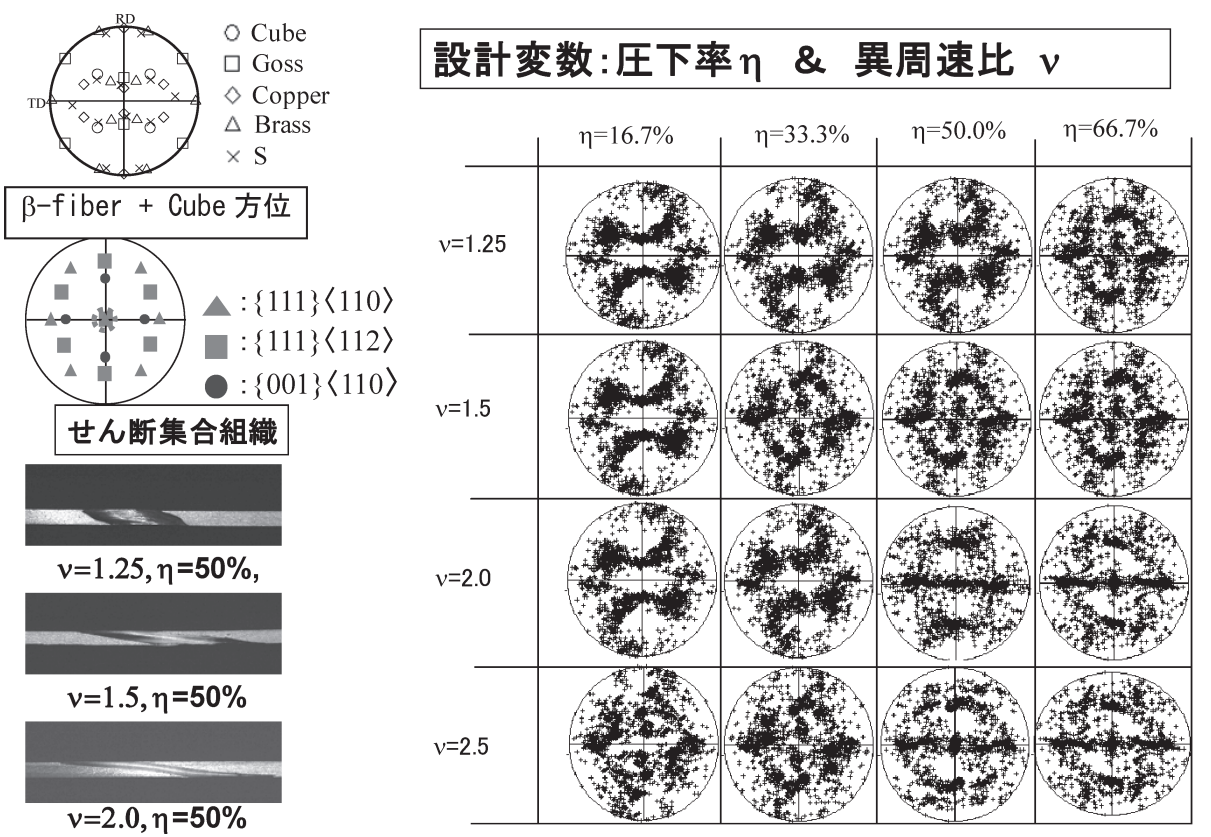

図8 異周速圧延プロセスのマルチスケール有限要素解析結果（16圧延条件による板中央層の $\{111\}$ 正極点図の比較）
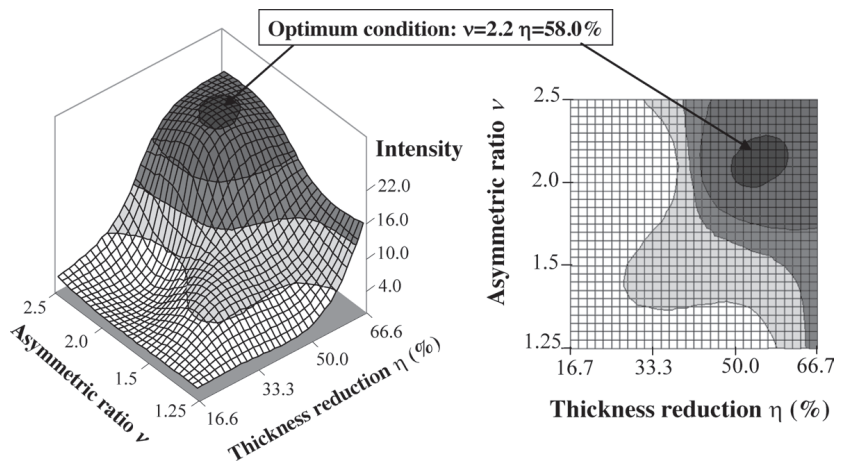

図 92 設計変数 (圧下率 $\eta$ および異周速比 $v$ ) 座標におけ る評価関数 ( $\{111\}$ 集合組織集束率 $)$ 曲面図

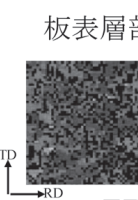

Experiment

FE results
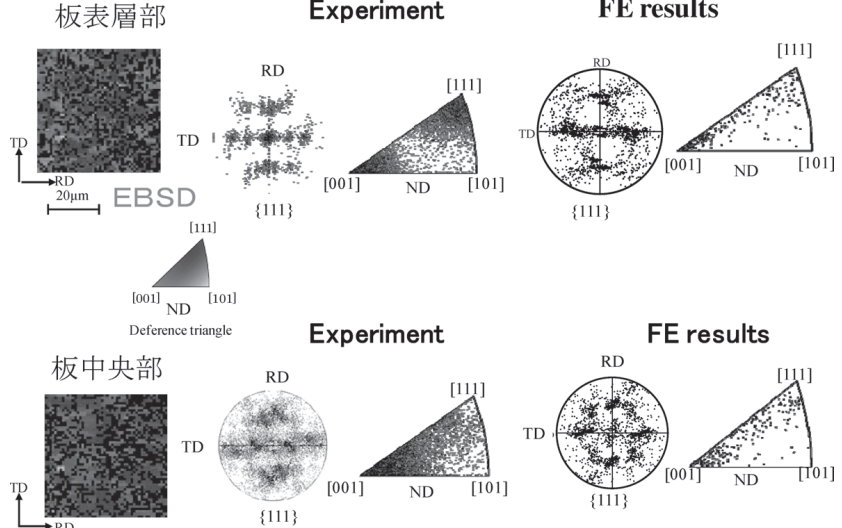

$\underset{20 \text { um }}{\mathrm{RD}}$ EBSD

図 10 異周速圧延の最適条件 (近傍)による板材中央部 および表層部のEBSD計測と結晶方位分布に関 する実験と結晶塑性マルチスケール有限要素解 析結果との比較

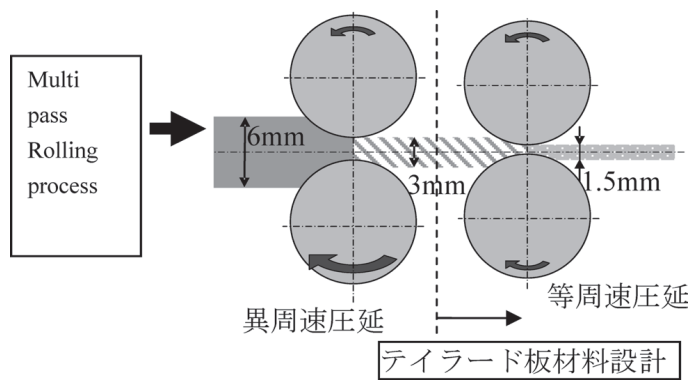

図 112 段圧延 (1段目異周速・2段目等周速圧延) の模 式図（2段目等周速圧延前板材の材料結晶方位分 布設計)
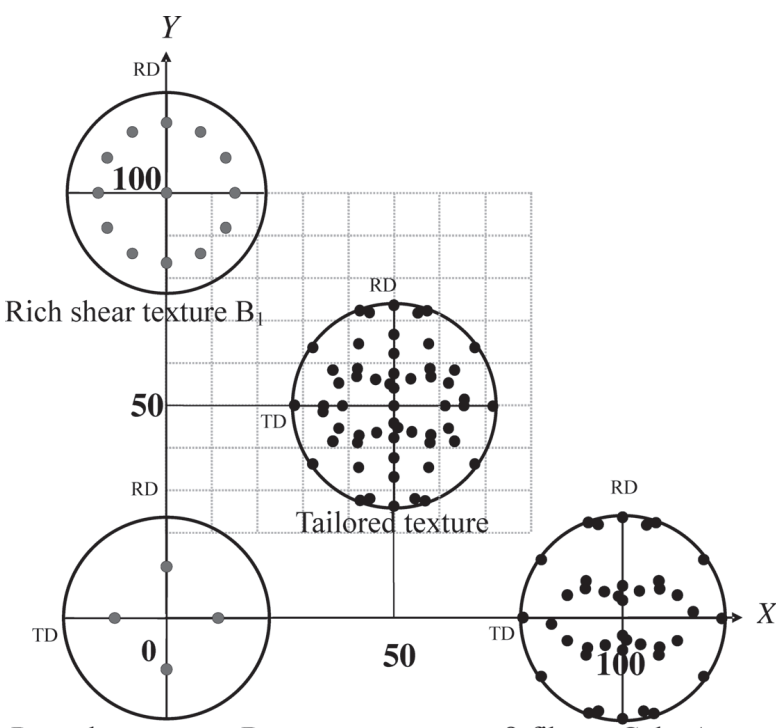

Poor shear texture $\mathrm{B}_{2}$

$\beta$-fiber + Cube A

図 12 テイラード集合組織板材設計：圧延集合組織比 率と優良せん断集合組織比率の組合せによる結 晶集合組織候補図 


\section{4. テイラード集合組織板材料設計 ${ }^{16)}$}

図11に2段圧延の模式図を示す。1段目の圧延と熱処理と の組合せによりテイラード結晶集合組織を形成し，2段目の 等周速圧延に供給する。2段目の等周速圧延の条件は圧下率 $50 \%$ とする。なお，実際には熱処理によっても集合組織は方 位変化を生じるが, 本解説では, 各集合組織は独立して存在 し，その割合を自由に変化させることができると仮定して解 析を行った。

$\beta$-fiber+Cube 方位を A， せん断集合組織を B，せん断集合 組織における $\{111\}$ 面が板面と一致する集合組織を優良せ ん断集合組織 $\mathrm{B}_{1},\{001\}$ 面が板面と一致する集合組織を劣化 せん断集合組織 $\mathrm{B}_{2}$ とする。 $\mathrm{B}_{1}$ は鋼板の $\gamma$ ファイバに相当し成 形性（ $r$ 值）を向上させる組織であり， $\mathrm{B}_{2}$ は逆に成形性を劣 化させるものである。つぎに示す $\mathrm{A}, \mathrm{B}_{1}, \mathrm{~B}_{2}$ の組合せにより

$$
\begin{aligned}
& X=\mathrm{A} /(\mathrm{A}+\mathrm{B}) \times 100, \quad \mathrm{~B}=\mathrm{B}_{1}+\mathrm{B}_{2} \\
& Y=\mathrm{B}_{1} / \mathrm{B} \times 100
\end{aligned}
$$

の2設計変数を定義した。図12に圧延集合組織成分比率 $X$ と 優良せん断集合組織比率 $Y$ の組合せにより求めた結晶集合組 織候補を示す。目的関数 (評価值)としては, $r$ 值の大きい值 と $|\Delta r|$ の小さい值を同時実現するために両値を組合せた多目 的関数值を定義した。図 13 に以下の 2 設計変数值を採用した。

$$
\begin{aligned}
& X=0 \%, 20 \%, 50 \%, 80 \% \\
& Y=20 \%, 50 \%, 80 \%, 100 \%
\end{aligned}
$$

16 条件の解析結果をもとに求めた多目的評価関数值の応 答曲面等高線図を図 13 に示す。これにより初期集合組織に おいて $\{111\}$ 集合組織の割合が多ければ多いほど等周速圧 延後の $\{111\}$ 集合組織の残存率が高いことがわかった。以 上の結果から, 高い平均 $r$ 值と低い $|\Delta r|$ の值を示す最適結晶 集合組織として， $X=52.0, Y=56.6$ の条件を得た。本最適条件 の結晶方位分布を持つ圧延前の板材を等周速圧延することで 得られた板材の $\{111\}$ 正極点図を市販の自動車用アルミニ ウム板材 6022-T43 と比較した結果を図 14 に示す。図は板厚 方向中央部の方位分布の比較であるが，\{111\} 集合組織成分 の残存率が高いことが確認されたと考える。さらに，圧延後 板材の $r$ 值の圧延方向からの角度による相違を 6022-T43板材 と比較した結果を図 15 に示す。平均ランクフォード值 $r$ およ び面内異方值 $\Delta r$ ともに改善されていることがわかる。最後

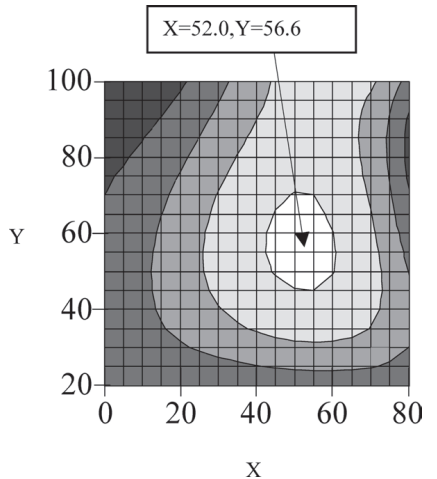

図 13 圧延集合組織比率 $X$ および優良せん断集合組織 比率 $Y$ 座標面上の多目的評価関数值等高線 $($ 多目 的評価関数值は平均ランクフォード值 $\bar{r}$ と面内異 方偏差值 $\Delta r に よ り$ 求められた）

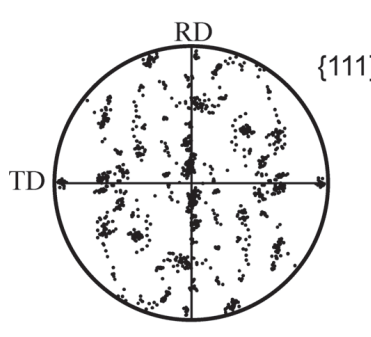

(a) Optimum texture

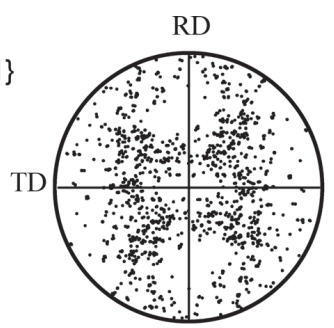

(b) A6022-T43 automotive sheet
図 14 最適テイラード結晶方位分布板材 (圧延前)の等 周速圧延後板材および市販自動車用アルミニウ 厶板材 6022-T43の $\{111\}$ 正極点図の比較

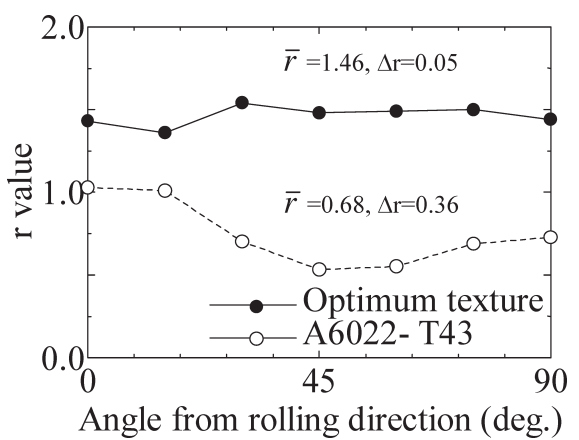

図 15 最適テイラード結晶方位分布板材 (圧延前)の等 周速圧延後板材および市販自動車用アルミニウ ム板材 6022-T43のランクフォード值の圧延方向 からの角度による相違, および平均ランク フォード值 $\bar{r}$ および面内異方值 $\Delta r$ の比較
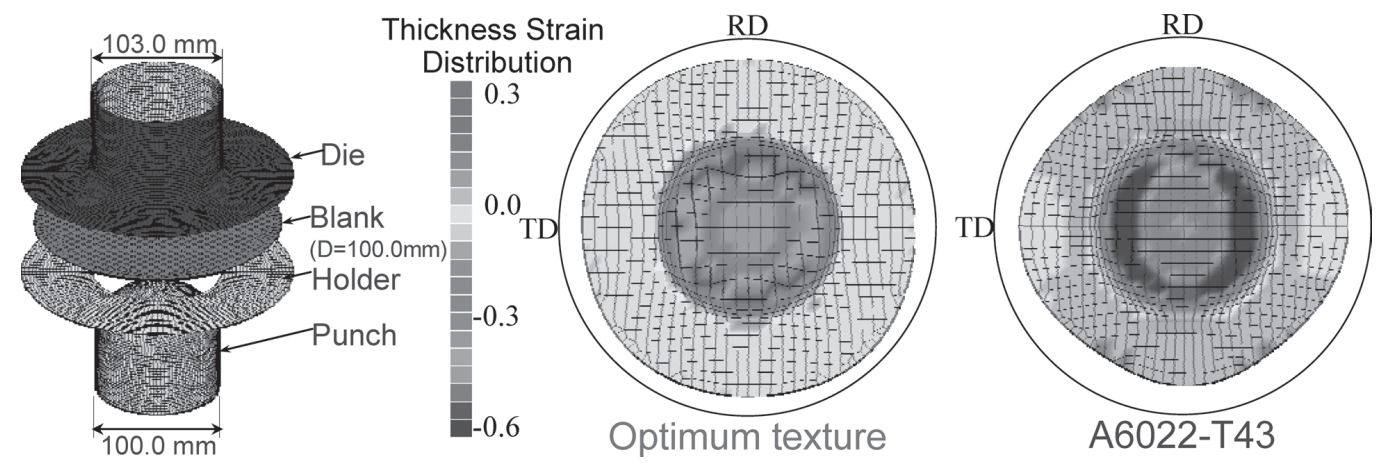

図 16 最適テイラード結晶方位分布板材 (圧延前) の等周速圧延後板材および市販自動車用アルミニウム板材 $6022-$ T43の球頭パンチ絞りで生じた耳の比較 
に, 圧延後の板材を用いて球頭パンチ深絞りの解析を行った 結果を図16に示す。6022-T43板材に比べ耳の発生が大幅に 改善されたことがわかる。

\section{5. 結言}

本解説では，微視集合組織および巨視成形能の予測可能な 結晶塑性マルチスケール有限要素法と離散最適化法を組合せ たプロセスメタラジー解析手法について概説した。設計変数 を異周速比と圧下率, 目的関数を $\{111\}$ 集合組織への結晶 方位の集積密度とした異周速圧延最適設計では異周速比 $v=$ 2.2 , 圧下率 $\eta=58 \%$ が最適条件であるという結果を得た。ま た，等周速圧延前の板材料最適集合組織設計では，最適な圧 延集合組織成分とせん断集合組織の割合を求めることができ た。これより，マルチスケール解析の応用として高成形能板 材料の創製に利用可能なプロセスメタラジー解析の可能性を 示すことができたと考える。

\section{参考文 献}

1) H. Jin and D. J. Lloyd: Journal of Materials Science and Engineering, 399 (2005), 358-367.

2) J. J. Park and N. J. Park: Journal of Materials Processing Technology,
169 (2005), 299-307.

3) S. B. Kang, B. K. Min, H. W. Kim, D. S. Willkinson and J. D. Kang: Metallurgical and Materials Transactions A, 36 (2005), 3141-3149.

4）左海哲夫，宇都宮裕，齋藤好弘：軽金属，52 (2002)，518-523,

5) A. B. Richelsen: International Journal of Mechanical Sciences, 39 (1997), 1199-1211.

6) E. Nakamachi, N. N. Tam and H. Morimoto: International Journal of Plasticity, 23 (2007), 450-489.

7) T. Ohata, Y. Nakamura, T. Katayama and E. Nakamachi: Journal of Materials Processing Technology, 143-144 (2003), 667-672.

8) K. Terada, K. Yuge and N. Kikuchi: Formulation, Journal of Japan Society for Mechanical Engineering (A), 61 (1995), 91-97.

9) L. Capolungo, C. Jochum, M. Cherkaoui and J. Qu: International Journal of Plasticity, 21 (2005), 67-82.

10) J. Pan and J. R. Rice: International Journal of Solids and Structures, 19 (1983), 973-987.

11）長島晋一：集合組織，丸善，（1984）

12）小山克己, 小松原俊雄 : 塑性と加工, 50 (2009), 211-215.

13) H. Inoue and T. Takasugi: Materials Transaction, 48 (2007), 20142022.

14）轟 章：日本機械学会, 99 (1999), 11-23.

15) H. J. Bunge and C. Esling: Deutsche Gesellschaft fur Metallkunde, (1982), 73-107.

16) E. Nakamachi, H. Kuramae, H. Sakamoto and H. Morimoto: Int. J. Mech. Sci., 52 (2010), 146-157. 